\title{
IMPLEMENTASI MODEL DAN METODE \\ MENGAJAR DALAM PENDIDIKAN ISLAM
}

\begin{abstract}
Nurhayati
ABSTRAK

Model dan metode pengajaran memilki arti penting, karena dengannya menjadi wahana keberhasilan tujuan pendidikan. Penerapan model dan metode mengajar yang tidak tepat, berakibat pada kegagalan pendidikan. Model dan metode pengajaran initelah lama dipraktekkan Rasulullah SAW, ketika beliau berda di Makkah dan Madinah, model dan metode pengajaran inilah yang kemudian menjadi cikal bakal munculnya model dan metode pengajaran masa kini. Karena itulah, uraian tentang model dan metode mengajar sangat menarik untuk dikaji secara cermat dan mendalam.
\end{abstract}

Kata kunci: model, metode, pendidikan Islam

\section{LATAR BELAKANG}

Pendidikan adalah bagian yang tidak terpisahkan dari ajaran Islam secara keseluruhan, ia merupakan bagian yang terpadu dari aspek-aspek Islam. Karena itu, dalam sejarah dikatakan bahwa Nabi Muhammadad SAW sangat mementingkan pendidikan. Beliau senantiasa menempatkan pendidikan sebagai sesuatu yang urgen dengan cara mengadakan pengajaran (ta'lim) kepada para sahabatNya supaya mereka memahami ajaran-ajaran Islam secara universal. ${ }^{1}$ Upaya Nabi Muhammad SAW dalam mengajar sahabat-sahabatNya, sebenarnya menjadi misi utamaNya. Misi tersebut sesuai yang terdapat dalam ayat yang pertama kali turun "iqra" perintah membaca.

Jika dapat dikatakan, kegiatan belajar mengajar sebagai sebuah sistem pendidikan bagi ummat manusia, terutama umat Islam pada khususnya merupakan kebutuhan dasar untuk memenuhi fungsi, peran dan eksistensi kemanusiaannya. Kebutuhan akan belajar dan mengajar ini, setara dengan kebutuhan manusia terhadap sandang, pangan dan papan. Tanpa kegiatan belajar dan mengajar, manusia tidak mampu memenuhi esensi kemanusiaannya sebagai manusia paripurna di hadapan Tuhan.

\footnotetext{
${ }^{1}$ Bahaking Rama, sejarah pendidikan Islam: Pertumbuhan dan Perkembangan hingga masa Khulafaurrasyidin (Jakarta: Paradotama Wiragemilang, 2002), h. 5
} 
Di sisi lain, dapat dikatakan bahwa, tanpa kegiatan belajar mengajar manusia tidak akan mengalami perkembangan dan kemajuan dalam hidupnya. Ibarat binatang yang melatadi atas bumi tidak mengetahui arah hidupnya, hendak kemana, untuk apa hidup, dan sesudah hidup di mana akan berada. Untuk kegiatan belajar dan mengajar tersebut diperlukan adanya sebuah model dan metode pengajaran.

\section{PENGERTIAN MODEL DAN MODEL MENGAJAR}

Sebelum mengemukakan pengertian "model dan metode mengajar", terlebih penulis menguraikan apa yang dimaksud "mengajar". Dalam hal ini, istilah mengajar berasal dari kata "ajar" artinya: petunjuk yang diberikan kepada orang yang diketahui dan dituruti. $^{2}$ Dari kata "ajar" tersebut lahirlah istilah lain, yakni belajar dan mengajar yang keduanya saling berkolerasi. Belajar adalah berusaha memperoleh kepandaian atau ilmu pengetahuan. Sementara mengajar berarti memberi pelajaran kepada peserta didik.

Istilah belejar dan mengajar yang saling berkolerasi itu, oleh pakar pendidikan menjadikannya dalah satu istilah, yakni "pengajaran". Dengan kata lain, dalam makna "pengajaran" di dalamnya mencakup kegiatan belajar dan mengajar. Dalam pandangan Ahmad Tafsir, pengajaran adalah suatu kegiatan yang menyangkut pembinaan anak mengenai segi kognitif dan psikomotor semata-mata, yaitu supaya pengetahuan anak lebih banyak, lebih cakap berpikir kritis, sistematis, dan obyektif, serta terampil dalam mengerjakan sesuatu. ${ }^{3}$ Dari batasan ini, dipahami bahwa pengajaran adalah bagian dari makna pendidikan.

Selanjutnya, Kata "model" berarti pola, contoh, acuan, dan ragam dari sesuatu yang akan dihasilkan. ${ }^{4}$ Sedangkan kata metode berarti cara yang dalam bahasa disebut al-manhaj atau al-wasilah, ${ }^{5}$ yakni sistem atau pendekatan serta sarana yang digunakan untuk mengantar kepada suatu tujuan. Dalam QS. al-Maidah (5): 35 Allah berfirman

$$
\text { و ابتغو النه الوسلةو جاهدو افى سبله }
$$

2 Departemen Pendidikan dan Kebudayaan, Kamus Besar Bahasa Indonesia,Ed-isi III (Cet.II; Jakarta:Balai Pustaka, 2002), h.17

${ }^{3}$ Ahmad Tafsir, Metodologi Pengejaran Agama Islam (Cet. VIII; Bandung: Remaja Rosdakarya, 2004),

h.7

${ }^{4}$ Departemen Pendidikan dan Kebudayaan, op.cit., h. 751

${ }^{5}$ Luwis Ma'luf,al-munjid fi al-lugha (Cet.XX; Bairut: Dar al-Masyriq, 1977), h. 912. 
Dan carilah metode/sarana yang mendekatkan diri kepada-Nya, dan berjihadlah pada jalan-Nya, supaya kamu mendapat keberuntungan.

Berdasarkan batasan pengertian tersebut, dapat dirumuskan bahwa model mengajar dan metode pengajar memiliki perbedaan yang mendasar. Dalam hal ini, model mengajar yerkait dengan sistem yang dalam kegiatan mengajar, sementara metode mengajar adalah cara dan upaya yang dilakukan dalam kegiatan mengajar.

Kaitannya dengan pengajaran dalam perspektif Islam, maka dalam sejarah diketahui bahwa, model pengajaran yang dilakukan oleh Rasulullah saw baik di Makkah maupun Madinah, beliau mengajar sahabat-sahabatnya dengan cara memberi nasihat, ceramah, diskusi, dan sebagainya. ${ }^{6}$

Berdasarkan fakta sejarah Islam diatas, maka dipahami bahwa model dan metode mengajar yang tepat, sesungguhnya telah dipraktekkan oleh Rasulullah saw. Di sisi Lain, dipahami pula bahwa model dan metode pengajaran Rasulullah saw tersebut, masih dapat di kembangkan di era kekinian sehingga pada gilirannya melahirkan banyak sekali format model dan implementasi metode pengajaran yang kita temukan dalam dunia pendidikan islam saat ini.

\section{FORMAT MODEL MENGAJAR DALAM KEGIATAN PENGAJARAN}

Dlam berbagai buku pendidikan, ditemukan sekurang-kurangnya empat model pengajaran, ${ }^{7}$ dan dari keempat model tersebut melahirkan berbagai bentuk variasi dalam mengajar. ${ }^{8}$ Empat model mengajar yang dimaksud adalah :

1. Model mengajar konsentris, yakni seluruh bahan ajar dijalani beberapa permulaan hingga akhir, dimulai dari yang paling mudah dan paling penting. Pemikiran itu, lebih mudah dipahami lewat gambar berikut: ${ }^{9}$

\footnotetext{
${ }^{6}$ Lihat Bahaking Rama, op cit., h. 11-12.

${ }^{7}$ Lihat misalnya ahmad Tafsir, op. cit. h. 38-39. Abu Ahmadi dan nur Uhbayanti, Ilmu pendidikan ( Cet. I ; Jakarta : rineka cipta, 1991), h.93-94. Muh.Ali, Guru dlam Proses Mengajar ( Bandung: sinar Baru, 1987), h. 58.

${ }^{8}$ Lihat Moh. Uzer Usman, Menjadi Guru Profesional 9Bandung: PT. Remaja Rosdakarya, 2004), h. 8485.

${ }^{9}$ Gambar tersebut dikutip dari Ahmad Tafsir, op.cit., h. 38.
} 


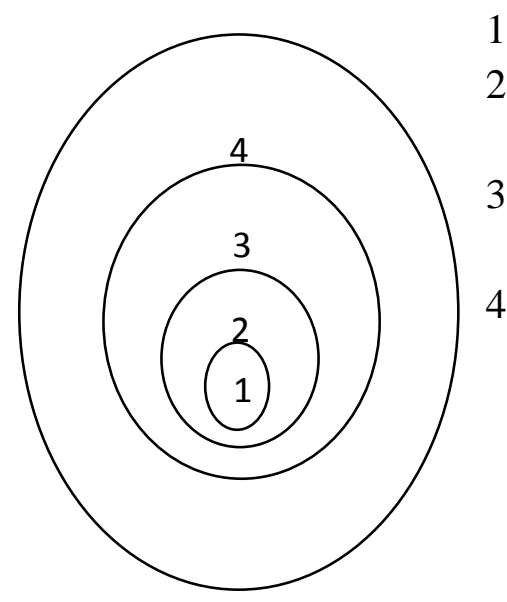

1. Penguraian pertama

2. Penguraian kedua, yang mencakup juga bahan pertama

3. Penguraian ketiga, yang mencakup juga bahan ke-1 dan 2

4. Dan seterusnya.

Konsep yang terkandung di dalam gambar di atas, dapat diterapkan di dalam merencanakan langkah-langkah proses belajar mengajar. Langkah pertama menguraikan bahan (1), langkah kedua menguraikan bahan (1) diperluas dengan bahan (2), langkah ketiga menguraikan bahan (1) dan (2) diperluas bahan (3), dan seterusnya.

2. Model Mengajar suksessif yang berarti pengajaran urutan atau berurutan. Di dalam jalan pelajaran ini seluruh bahan hanya dilalui satu kali, karena pengajaran maju secara berurutan. Jalan pengajaran ini dapat digambarkan sebagai berikut: ${ }^{10}$

\begin{tabular}{l|l|l|l|l} 
Bagian 1 & Bagian 2 & Bagian 3 & Bagian 4 & dan seterusnya \\
\hline
\end{tabular}

Seandainya dikehendaki, konsep yang terkandung di dalam model pengajaran ini dapat diterapkan dalam merencanakan langkah-langkah kegiatan belajar-mengajar dengan cara merencanakan langkah-langkah, yakni langkah pertama, menerangkan $\mathrm{Bab} 1$; langkah kedua, menerangkan Bab 2; langkah ketiga, menerangkan Bab 3; dan seterusnya.

3. Model pengajaran sintesis, yakni menunjukkan model kegiatan belajar-mengajar yang dimulai dari mempelajari unsure-unsur atau bagian-bagian untuk selanjutnya membuat kesimpulan atau merumuskan keseluruhan. Dalam pengajaran membaca misalnya, jalan pengajaran ini akan dilakukan dengan memulai proses pengajaran dengan mengenali huruf-huruf, lalu suku kata, kalimat untuk selanjutnya cerita. Pengajaran agama Islam misalnya yang dilakukan oleh Rasulullah saw, beliau mula-mula mnegajarkan apa itu definisi iman, definisi Islam, dan definisi ihsan. Demikian pula, dalam mengajarkan bab sholat umpamanya, akan dimulai dari

${ }^{10}$ Gambar tersebut dikutip dari ibid., h. 39 
pengenalan rukun, syarat, bacaan, kemudian dirangkaikan menjadi tubuh shalat yang utuh.

4. Model mengajar analisis, yakni kebalikan model pengajaran sintesis. Dimulai dari yang umm, menuju yang khusus; dari keutuhan menuju bagian-bagian. Prinsip yang mendasarinya ialah model deduktif. ${ }^{11}$

Keempat model mengajar di atas merupakan model teoritis yang dapat dikembangkan dalam bentuk variasi (macam-macam gaya) mengajar sebagai pola interaksi guru dan murid. Sardiman A.M. menjelaskan bahwa yang dimaksud dengan variasi interaksi ialah frekuensi atau banyak sedikitnya pergantian aksi antara guru dengan siswa, dan siswa dengan siswa secara cepat. ${ }^{12}$ Sudah sewajarnya bahwa dalam pergaulan antara individu di dalam kelas akan tercipta bentuk saling aksi dan mereaksi yang disebut interaksi edukatif. Dalam interaksi edukatif diharapkan semua yang di dalamnya berperan aktif, sehingga tercipta komunikasi timbal balik antara guru dengan murid, dan murid dengan murid.

Model interaksi guru dangan muriddalam kegiatan belajar mengajar sangat beraneka ragam coraknya, mulai dari kegiatan dominasi oleh guru sampai kegiatan sendiri yang dilakukan oleh murid. Hal ini bergantung pada keterampilan guru dalam mengelola kegiatan belajar mengajar.

Penggunaan variasi model interaksi, dimaksudkan agar tidak menimbukan kebosanan, kejenuan murid, serta untuk menghidupkan suasan kelas demi keberhasilan murid mencapai tujuan. Adapun pola interaksi (gaya interaksi) yang digambarkan oleh Usman adalah sebagai berikut:

a. Model guru-murid, yakni komunikasi untuk aksi (satu arah)

b. Model guru-murid-guru, yakni ada balikan (feedback) bagi guru, tidak ada interkasi antara siswa.

c. Model guru-muid-murid, yakni ada balikan bagi guru, siswa slaing belajar satu sma lain.

d. Model guru-murid, murid-guru, murid-murid, yakni interaksi optimal guru dengan murid dan antara murid dengan murid, atau disebut juga dengan komunkasi sebagai transaksi, multiarah.

e. Model melingkar, yakni setiap siswa mendapat giliran untuk mengemikakan smabutan atau jawaban, tidak diperkenankan berbicara dua kali apabila setiap siswa belu mendapat giliran. ${ }^{13}$

\footnotetext{
${ }^{11}$ Lebih lanjut lihat Ahmad Tafsir, op. cit, h. 39.

${ }^{12}$ Sardiman A.M. Interaksi dan Motivasi Belajar Mengajar ( Jakarta: PT. RajaGrafindo Persada, 2000), h. 81-82.

${ }^{13}$ Lihat Muh.Uzer Usman, op, cit., h. 87-88
} 
Untuk lebih jelasnya, berikut ini dikemukakan bagan-bagan tentang Model interaksi variasi mengajar.

\section{Bagan I}

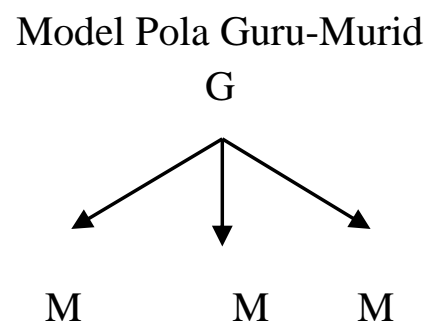

\section{Bagan II}

Model Pola Guru-Murid-Guru
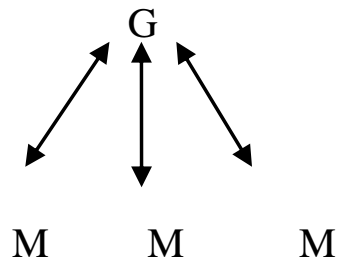

\section{Bagan III}

Model Pola Guru-Murid-Murid

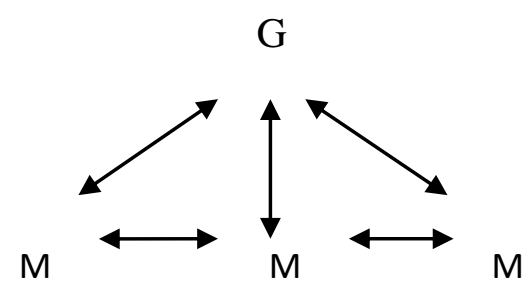

Bagan IV

Model pola Guru-Murid, Murid-Guru, Murid-Murid

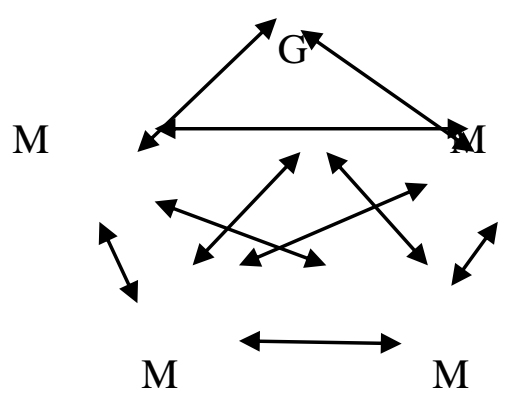




\section{Bagan V}

Model Pola Melingkar

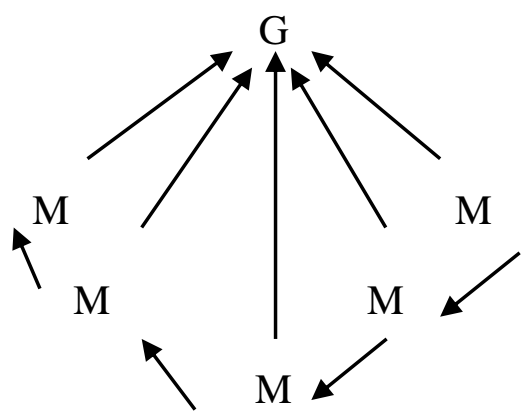

\section{IMPLENENTASI MODEL MENGAJAR DALAM DUNIA PENDIDIKAN (MEMAHAMI METODOLOGI PENGAJARAN PERSPEKTIF ISLAM)}

Bila dipahami bahwa metode sebagai suatunsubsistem ilmu pendidikan Islam ayng berfungsi sebagai alat pendidikan, maka seluru firman Allah SWT, juga sabda nabi saw, adalah sebagai sumber ilmu pendidikan islam mengandung implikasiimplikasi metodologis yang konprehensif mencakup semua aspek kemungkinan pertumbuhan dan perkembangan pribadi manusia. Berkenaan dengan itulah, pemahaman terhadap metode pengajaran snagat dituntut peranannya dalam menemukan metodologi yang tesendiri yang lebih tepat dan lebih mengarah pada orientasi Islam, guna pencapaian tujuannya, dan untuk lebih jelasnya berikut ini dikemukakan metode-metode pendidikan yang dimaksud :

1. Metode Berpikir Analitis dan Sistensis

Ajaran agama (Islam) senantiasa mendorong manusia untuk menggunakan akl pikirannya dalam menelaah dan mempelajari gejala kehidupannya sendiri dan gejala kehidupan alam sekitarnya. Dalam Qs. al-Gasyiah (88): 17-21 misalnya, Allah swt berfirman:

$$
\text { سطحت ينظرون الى الابل كيف خلقت (مذر) و الى السماء كيف رفعت() و الى الجبال كيف نصبت() و الارض كيف }
$$

Maka apakah mereka tidak memperhatikan unta bagaiman ia diciptakan, Dan langit, bagaimana ia ditingginkan? Dan gunung-gunung ia di tegakkan? Danbumi ia di hamparkan? Maka berilah ia peringatan, karena sesungguhnya kamu hanyalah orang-orang yang memberi peringatan. ${ }^{14}$

\footnotetext{
${ }^{14}$ Departemen agama RI, Al-Qur"an dan Terjemahnya (jakrta: Proyek Pengadaan Kitab Suci al-Qur'an,
} 1992),h. 1054-1055. 
Disamping term afalza yanzurun yang memberikan dorongan secara sistematis untuk berpikir analitis dan sintesis, juga ditemukan term-term lain dalam al-Qur'an yang mengajak mnausia untuk menggunakan akal pikirannya misalnya ; afala ta'kilun, (apakah kamu tidak melihat;) afala tatafakkarun (apakah kam tidak menggunakan nalar); ya ulil albab (hai orang-orang yang memiliki otak dan akal) dan selainnya. Berkenaan dengan term-term inilah, Allah swt mendorong manusia untuk lebih mengembangkan akal pikirannya dalam berbagai proses dan cara, baik secara induktif, maupun deduktif.

2. Metode bimbingan dan Penyuluhan

Dalam islam terdapat ajaran yang mengandung metode bimbingan dan penyuluhan, justru karena Al-Qur'an sendiri diturunkan untuk membimbing manusia, dan Nabi saw diutus dengan perannya sebagai pemberi penyuluhan dan menasehati umat manusia. Sehingga, mereka dapat memperoleh kehidupan batin yang tenang, sehat serta bebas dalam konflik kejiwaan. Dengan metode ini, manusia akan mampu mengatasi segala bentuk kesulitan hidup yang dihadapinya.

Dalam QS. Yunus (10): 57 Allah swt berfirman

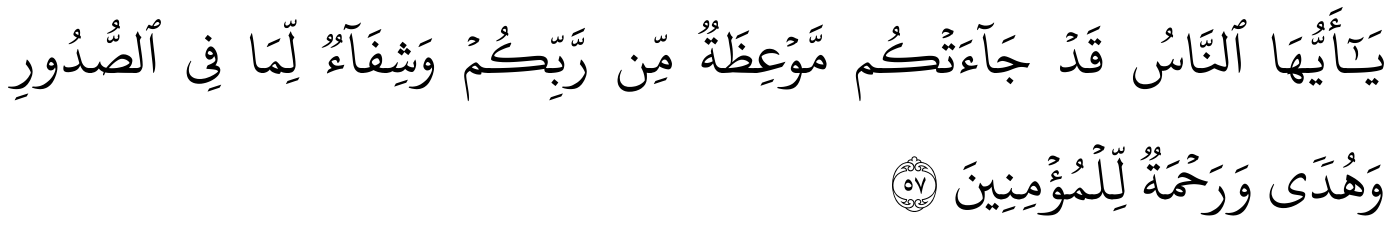

Wahai manusia, sesunguhya telah datang kepadamu pelajaran dati Tuhanmu dan penyembuh bagi penyakit-penyakit (yang berada) dalam dada dan petunjuk serta rahmat bagi orang-orang yang beriman. ${ }^{15}$

Selaku nabi dan rasul, Muhammad saw telah memberikan contoh bagaiman metode beliau membimbing umat kepada ajaran agama yang dibawanya. Mesipun beliau telah sukses dalam membimbing umatnya, namun dlam kehidupan sehariharinya tetap sederhana. Berdasarkan pada pengalaman Nabi saw tersebut, mengindikasikan bahwa metode bimbingan dan penyuluhan sangat penting dalam proses pendidikan.

3. Metode Targhib dan Tarhib

Metode thargib dan tarhib identik dengan metode motivasi, yaitu cara memberikan pelajaran dengan memberikan dorongan untuk memperoleh kegembiraan bila mendapatkan sukses dalam kebaikan, sedang bila tidak sukses karena tidak mau mengikuti petunjuk yang benar akn mendapatkan kesusahan.

15 Ibid., h.314 
Dengan demikian metod pendidikan dengan pola seperti ini, terkait dengan adanya pemberian motivasi disertai pemberian "ancaman" yakni suatu metode pendidikan dan pengajaran dengan cara pendidik memberikan hukuman atas kesalahan yang dilakukan pesertadidik dalam QS.Fussilat (41): 46 Allah swt berfirman:

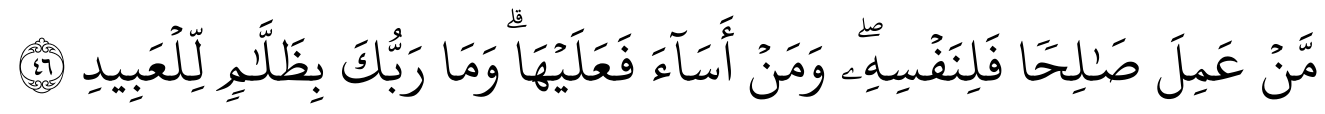

Barang siapa yang mengerjakan amal yang shaleh maka (pahalanya) untuk dirinya sendiri dan barang siapa yang berbuat jahat maka (dosanya) atas dirinya sendiri; dan sesekali tidaklah Tuhanmu menganiaya hamba-hamba (Nya). ${ }^{16}$

Dalam berbagai ayat juga disebutkan juga bahwa balasan kepada orang-orang yang beriman dan bermal shaleh, adalah berupa kegembiraan hidup disurga dan sebaliknya orang yang sesat dan yang tidak mentaati perintah Allah mendapatkan penderitaan di Neraka kelak.

4. Metode Praktik

Metode praktik (fuction), mendorong manusia untuk mengamalkan ilmu pengetahuan dan mengaktualisasikan keimanan dan ketakwaannya dalam hidup sehari-hari seperti yang terkandung dlam perintah shalat dan puasa, serta selainnya. Mengenai shalat misalnya, disebutkan dalam QS. Al-ankabut (29) :45, Allah swt berfirman:

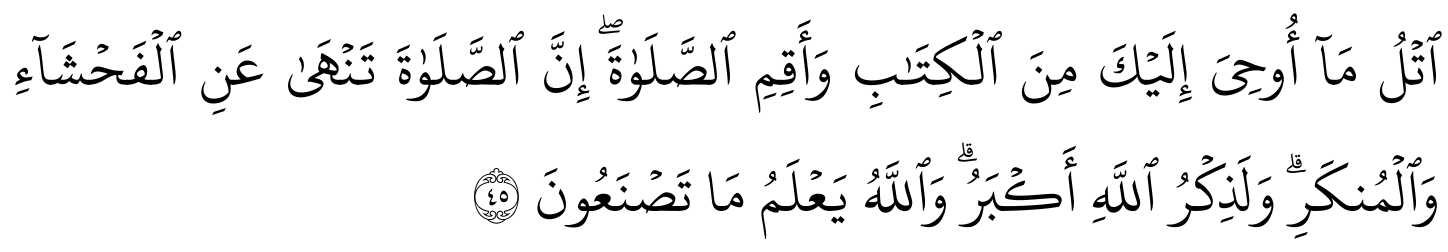

Bacalah apa yang telah di wahyukan kepadamu, yaitu al-Kitab (al-Qur'an) dan dirikanlah shalat. Sesungguhnya shalat itu mencegah dari (Perbuatan-perbuatan) keji dan munkar. Dan sesungguhnya mengingat Allah (shalat) adalah lebih besar (keutamaannya dari ibadah-ibadah yang lain). Dan Allah mengetahui apa yang kamu kerjakan. ${ }^{17}$

Kemudian dan praktiknya, disebutkan dalm hadits Nabi saw;

عن مالك قال النبي صلو ا كما رأيتموني أصلي فأْا حضرت الصلاة فليؤذن لكم أحدكم وليوْمكم أكبر كم

${ }^{16}$ Ibid., h. 780.

${ }^{17}$ Ibid., h. 635.

${ }^{18}$ Al-Bukhari, op. cit., dalam kitab al-Ahzan, hadis nomor 590. 
Dari Malik (bin Annas), bahwa Nabi saw bersabda: Shalatlah kalian sebagaiman kalian melihat (cara) ku shalat, dan apabila telah tiba waktu shalat hendaklah salah seorang di antara kalian azan, dan yang menjadi imam (shalat) adalah yang tertua (usianya) diantara kalian. (HR.al-Bukhari)

5. Metode Kelompok

Metode mendidik secara kelompok disebut metode mutual education, misalnya dicontohkan oleh Nabi saw sendiri dalam mengejarkan shalat dengan mendemonsrasikan cara-cara shalat dengan baik, termasuk dalam masalah dengan ketepatan waktu sesuai yang ditetapkan al-Qur'an sebagaimana dalam QS.Annisa (4) :103. 2

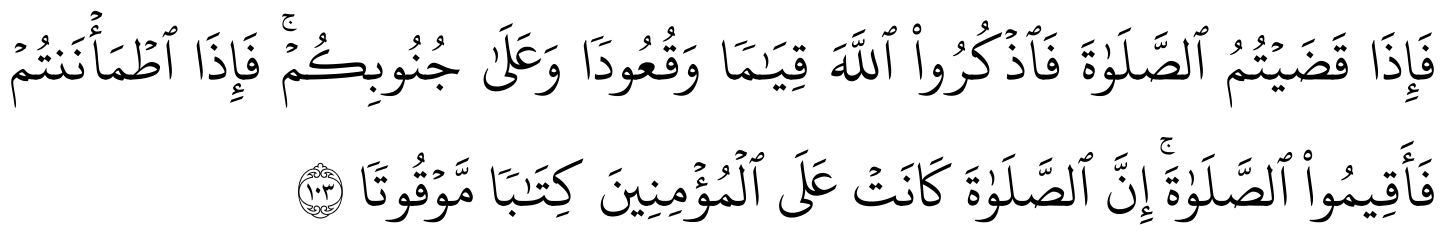

Sesungguhnya (pelaksanaan) shalat bagi orang-orang mukmin tentukan waktuwaktunya $^{19}$

Kemudian pemberian metode pendidikan sejarah berkelompok dalam implementasinya, Nabi saw menganjurkan agar shalat tersebut dilaksanakan berjamaah dengan nilai pahala 27 kali lipat. Dengan cara berkelompok inilah proses mengetahui dan memahami ilmu pengetahuan lebih efektif, oleh karena satu sama lain dapat saling bertanya dan saling mengoreksi bila satu sam lain melakukan kesalahan.

6. Metode Kisah

Metode kisah disebut bila metode bercerita yakni cara mendidik dengan mengandalkan bahasa, baik lisan maupun tulisan dengan menyampaikan pesan (messagelinlinformasi) dari sumber pokok sejarah islam, yakni al-Qur'an dan Hadis. salah satu metode yang digunakan al-Qur'an untuk mengarahkan manusia kearah yang dikehendakinya dengan menggunakan cerita(kisah) setiap kisah menunjang materi yang disajikan, baik kisah tersebut benar-benar terjadi maupun kisah simbolik. Dalam QS. yusuf (12). 2.111, Allah swt berfirman:

19 ibid., h. 138. 


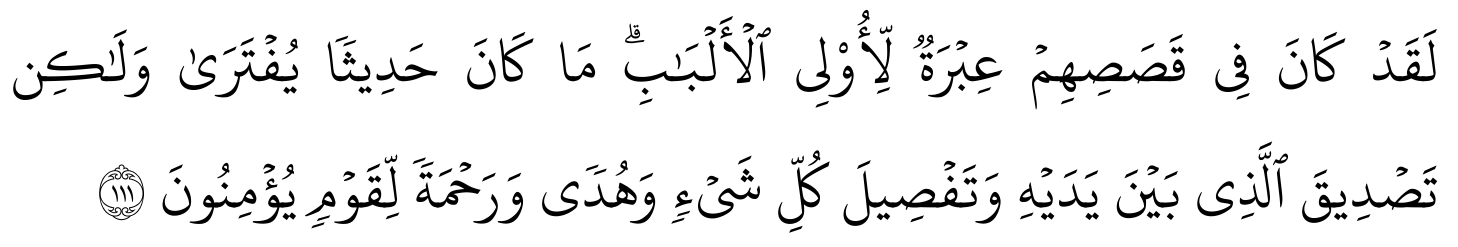

Sesungguhnya pada kisah-kisah mereka itu terdapat pengajaran bagi orangorang yang mempunyai akal. ${ }^{20}$

Kisah-kisah dlam al-Quran mengandung nilai pedagogis, terutama yang dijumpai pada kisah yang berkenaan dengan misi kerasulan dan umat masa lampau.

7. Metode Teladan

Metode telada adalah metode pemberian contoh dan dapat pula disebut metode "meniru yakni suatu metode pendidikan dan pengajaran dengan cara pendidik memberikan contoh teladan yang baik kepada anakdidk, kemudian pesertadidik menirunya. Dalam al-Qur'an, metode keteladanan di proyeksikan dengan kata uswah yang kemudian di beri sifat di belakangnya seperti sifat hasanah yang berarti teladan yang baik. Dalam QS. al-Ahzab (33):

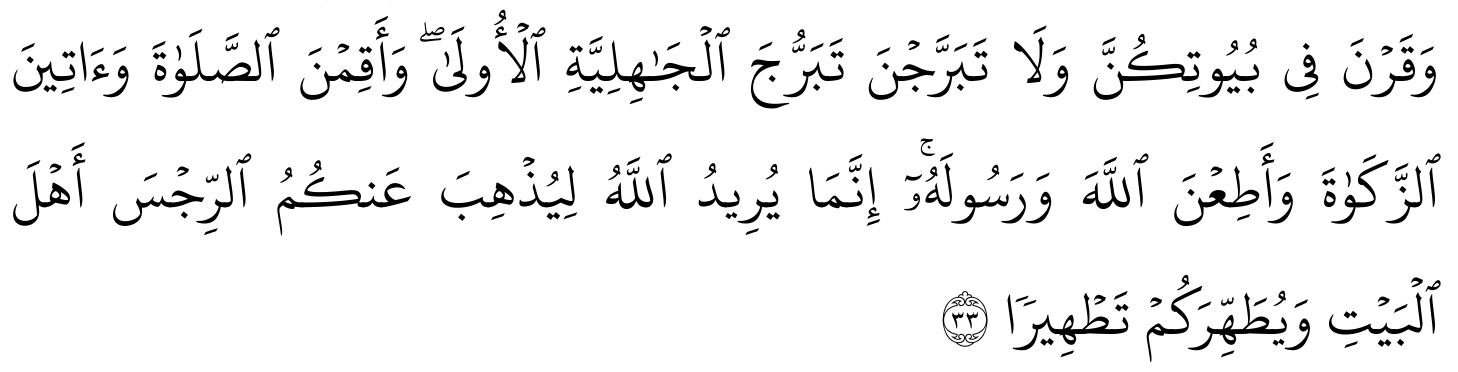

Sesungguhnya telah ada pada (diri) Rasulullah itu suri teladan yang baik bagimu (yaitu) bagi orang yang mengharap (rahmat) Allah dan (kedatangan) hari kiamat dan dia banyak menyebut nama Allah. ${ }^{21}$

Metode keteladanan dalam pendidikan Islam bertujuan untuk menciptakan akhlak al-mahmudah kepada peserta didik, sehingga terbuntuk pada setiap tingkah lakunya perbuatan yang baik.

8. Metode Diskusi

Metode diskusi adalah bertukar pikran dalam kegiatan pendidikan, dan hal ini sangat ditekankan oleh al-Qur'an dalam mendidik dan mengajar manusia dengan tujuan lebih memantapkan pengertian, dan sikap pengetahuan mereka terhadap suatu masalah.

\footnotetext{
${ }^{20}$ Departeman Agama RI, op. cit., h. 366

${ }^{21}$ Ibid., h. 670.
} 
Perintah Allah dalam mengajak manusia ke jalan yang benar harus dengan hikmah dan mau'izah yang baik, ${ }^{22}$ dan membantah mereka dengan berdiskusi secara benar. Dalam QS. al-Ankabut (29): 46, Allah swt berfirman:

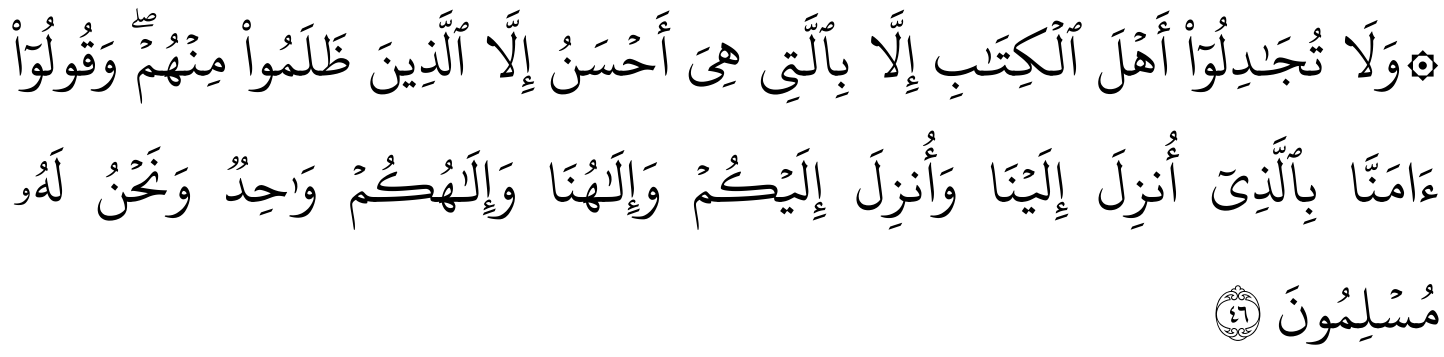

Dan janganlah kamu berdebat dengan Ahli Kitab, melainkan dengan cara yang

paling baik. ${ }^{23}$

Dengan berdiskusi, diharapkan dan diarahkan untuk sampai pada perumusan suatu kesimpulan. Dengan demikian, suatu diskusi memiliki arti dalam kegiatan pendidikan Islam bilamana dilakukan dengan persiapan yanga matang, terutama bahan-bahan yang akan didiskusikan.

9. Metode Tanya Jawab

Metode Tanya Jawab dalam pendidikan, adalah dengan cara berdialog atau wawancara. Metode seperti ini, sering dipakai oleh para Nabi dan Rasul Allah swt dalam mengajarkan agama yang dibawanya kepada umatnya. Bahkan para ahli pikir atau filsuf pun banyak mempergunakan metode Tanya jawab ini.

Firman Allah swt yang menyatakan bahwa hendaknyalah seseorang bertanya kepada orang yang ahli bila memang tidak mengetahui, adalah QS. al-Nahl (16)m: 43

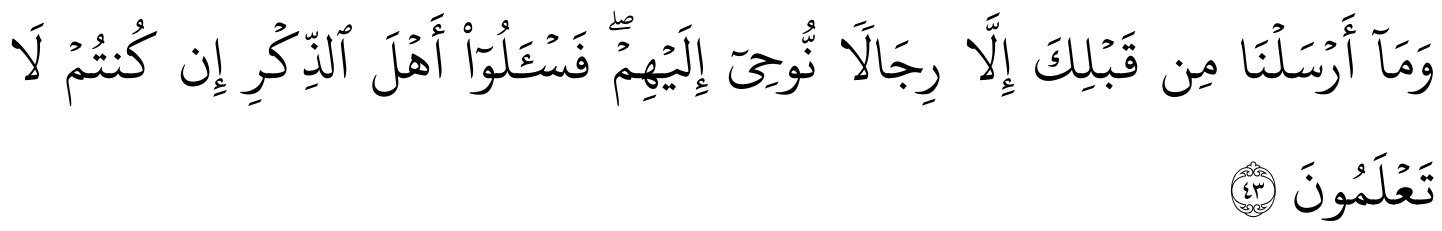

Maka bertannyalah kepada orang yang mempunyai pengetahuan jika kamu tidak mengetahui. $^{24}$

\footnotetext{
22 Lihat QS. al-Nahl (16): 125.

${ }^{23}$ Departemen Agama RI, op. cit, h. 635.

24 Ibid., h. 408.
} 
Dengan metode Tanya jawab, pengertian, dan penetahuan peserta didik dapat lebih dimantapkan, sehingga segalah bentuk kesalahpahaman, kelemahan daya tangkap terhadap pelajaran dapat dihindari. Dengan metode ini pula, peserta didik akan tampil berani bertanya agar pengetahuannya semakin bertambah.

10. Metode Pembiasaan

Metode pembiasaan adalah metode yang digunakan dalam pendidikan dengan cara melatih diri melalui kebiasaan yang dilakukan secara bertahap. Metode ini, pada gilirannya akan memantapkan pelaksanaan materi-materi ajaran Islam. Dalam kasus menghilangkan kebiasan meminum khamar misalnya, Al-Qur'an dengan memulai dengan menyatakan bahwa hal itu merupakan kebiasaan orangorang kafir, ${ }^{25}$ dilanjutkan dengan menyatakan bahwa khamar itu terdapat manfaat dan mudarat, namun mudaratnya lebih besar dari pada manfaatnya. ${ }^{26}$ Tahap berikutnya adlah pelanggaran dalam melaksanakan shalat dalam keadaan mabuk, ${ }^{27}$ dan tahap terakhir adalah penegasan bahwa meminum khamar dan perbuatan-perbuatan tercelah lainnya harus dijauhi. ${ }^{28}$

Berbagai metodologi pengajaran dalm pendidikan Islam yang telah dikemukakan, dianggap sangat efektif dan efisien di gunakan dlam dunia pendidikan dewasa ini. Dalam pandangan penulis bahwa rumusan metode pengajaran yang tepat dan yang terbaik, adalah senantiasa harus mengarah pada orientasi pengembangan ilmu pengetahuan yang bersumber dari Allah swt, pengembangan kea rah kehidupan sosial, dan pengembangan kearah alam sekitar untuk kepentingan hidup manusia.

\section{KESIMPULAN}

Mengajar diartikan memberi pelajaran kepada pesertadidik, yakni suatu kegiatan yang menyangkut pembinaan anak yang mengenai segi kognitif dan psikomotor supaya anak lebih banyak pengetahuannya, lebih cakap berpikir kritis, sistematis, dan obyektif, serta terampil dalam mengerjakan sesuatu. Kegiatan mengajar disini, merupakan bagian dari makna pendidikan. Model mengajar dan metode pengajar memiliki perbedaan yang mendasar. Dalam hal ini, model mengajar terkait dengan sistem yang dlam kegiatan mengjar, sementara metode mengajar adalah cara dan upaya yang dilakukan dlam kegiatan mengajar.

\footnotetext{
${ }^{25}$ Lihat QS.al-Nahl (16) :67.

${ }^{26}$ Lihat QS.al-Baqarah(2) :219.

27 Lihat QS.al-Nisa(4) : 43.

${ }^{28}$ Lihat QS. al-Maidah (5): 90
} 
Ada empat model mengajar yakni: model mengajar yang konsentris ; model mengajar suksessif ; model mengajar sintesis, dan model mengajar analisis.dari keempat model mengajar ini, melahirkan beberapa variasi model mengajar yakni; model murid-muris, yakni komuniasi sebagai aksi (satu arah) ; model gur-muridguru, yakni ada balikan (feetback) bagi guru, tidak ada interaksi antara siswa; model guru-murid-murid, yakni ada baliakn bagi guru, siswa saling belajar satu sama lain; model guru-murid, murit-guru, murid-murid, yakni interaksi optimal guru dengan murid dan antara murid dengan murid;modelmelingkar, yakni setiap siswa mendapat giliran untuk mengemukakan smabutan atau jawaban, tidak diperkenankan untuk berbicara dua kali apabila siswa belum mendapat giliran.

Dalam perspektif pendidikan islam, sekurang-kurangnya sepeuluh macam metode mengajar, yakni pengunaan metode berpikir analitis dan sintesis ; metode bimbingan dan penyuluhan; metode targhib dan tarhib; metode praktik; metode kelompok; metode kisah; metode teladan; metode diskusi; metode Tanya jawab; metode pembiasaan. 


\section{DAFTAR PUSTAKA}

Al-Qur'an al-Karim.

Ahmadi, Abu dan Nur Uhbayanti, Ilmu Pendidikan, Cet I; Jakrta : Rineka Cipta, 1991.

Ali, Muhammad, guru dlam Proses Mengajar. Bandung: Sinar Baru, 1987

Al-Bukhari, Dikutib dari Abu 'abd.Allah Muhammad ibn Ismail ibn Ibrahim ibnalmugirah ibn al-bardizbad Sahih al-Bukhari, jilid I.mesir: Dar al-ilm, 1992

Departeman agama RI, Al-Qur'an dan Terjemahnya. Jakarta Penggadaan Kitab suci al-Quran, 1992

Departemen Pendidikan dan Kebudayaan, Kamus Besar Bahasa Indonesia, Edisi III. Cet. II; Jakarta : Balai Pustaka, 2002.

Ma'luf, Luwis .al-munjibd fi al-Lugha. Cet. XX; Bairut : Dar al-Masyriq, 1997

Rama, Bahaking. Sejarah Pendidikan Islam : Pertumbuhan dan Perkembangan Hingga Masa Khulafaurrasyidin. Jakarta: Paradotama wiragemilang , 2002.

Sardiman A.M Interaksi dan Motivasi Belajar Mengajar. Jakarta: PT. Raja Grafindo Persada,2000.

Tafsir, Ahmad. Metodologi Pengajaran Agama Islam. Cet.VIII; Bandung Remaja Rosdakarya, 2004.

Usman Moh.Uzer. Menjadi Guru Profesional. Bandung: PT.Remaja Rosdakarya, 2004. 